\title{
TAKHRIJ AL-FURU' ALAL USUL PERIODE IJTIHAD DI MASA SHAHABAT DAN TABI'IN (Kajian Sosiologi - Antropologi Hukum Islam)
}

\author{
Erwan \\ Jurusan Syari'ah STAI-YDI Lubuk Sikaping \\ J1. Prof Dr. Hamka. No 16 Lubuk Sikaping \\ e-mail: erwanerwan81@gmail.com
}

\begin{abstract}
This research reveals the truth about the reality of Islamic law and its scope. This study was a library research. The data were obtained through the library method, namely by collecting data and materials from books that are relevant to this discussion, by reading, studying, and analyzing all the sources. Sociological-anthropological understanding means discussing the truth of a fact in depth. Law as something that is related to bumans, then the relationship between humans and other human beings is in a life interaction. Because without the interaction of life there will be no law (ibi societas ibi ius, zoon politicon). Law serves to regulate relations between people. But not all buman actions have their regulation. Only actions or behavior that are classified as legal actions. Legal law relations consist of bonds between individuals and individuals and between individuals and communities. In its efforts to regulate, the law adapts to the interests of society well. As a collection of rules or principles, the law has a general and normative content, the legal principle aims to protect the interests of human beings as social beings. Therefore the law must be obeyed, must be carried out and maintained, but not violated. Humans are given the mind to think, then ijtibad is the deployment of the ability of the brain. The real fact shows that thisdynamics had existed during the Prophet's benediction and tabiin.
\end{abstract}

Kata kunci: Sosiologi, Antropologi, Ijtihad, Hukum Islam

\section{PENDAHULUAN}

$S_{\text {pengetahuan, bertolak kepada apa }}^{\text {osiologi Hukum dalam ilmu }}$ yang disebut disiplin ilmu, yaitu sistem ajaran tentang kenyataan, yang meliputi disiplin analitis dan disiplin hukum (perskriptif). Disiplin analitis, seperti sosilogis, psikologis, antropologis, sejarah, sedangkan disiplin hukum meliputi: ilmuilmu hukum yang terpecah menjadi ilmu tentang kaidah atau patokan tentang prilaku yang sepantasnya, seharusnya, ilmu tentang pengertian-pengertian dasar dan sistem dari pada hukum dan lain-lain.
Hubungan yang cukup lama antara sistem hukum dari masyarakat dan kebudayaan-kebudayaan lain (the other cultures) selain state law (hukum negara) menjadikan sistem- sistem hukum tersebut berjalan secara dinamis sesuai dengan laju kebudayaannya. Sebagian pihak menganggap the other laws bagian dari masa lalu, namun sebagian lagi menyatakan bahwa mereka tetap eksis hingga kini. Dan, sebagian lainnya menyatakan ada, namun semakin terkikis.

Seperti diketahui, Alqur'an adalah salah satu bahkan satu-satunya kitab suci agama yang pada satu sisi 
melahirkan berbagai disiplin ilmu pengetahuan yang dihasilkan untuk memahami Alqur'an itu sendiri. Tidak ada kitab suci lain apalagi buku-buku biasa yang untuk memahaminya memerlukan perangkat ilmu pengetahuan yang dapat dibilang tidak terbatas. Demikian pula dengan ilmu pengetahuan yang dihasilkan dari padanya (kitab suci atau buku) selain alQur'an. Pertumbuhan takhrij seiring dengan perkembangan ushul figh, figh atau Hukum Islam.

Periode shahabat dan tabi'in merupakan periode tafsir dan takmil (penjelasan dan penyempurnaan) yang berlangsung selama 90 tahun kurang lebihnya, yaitu terhitung mulai kewafatan Rasulullah pada tahun $11 \mathrm{H}$ sampai dengan akhir abad pertama Hijriah $(101 \mathrm{H}$ atau 632-720 M). Dan masa setelah shahabat adalah masa thabi'in. Masa thabi'in adalah masa yang gemilang dalam perkembangan ijtihad.

\section{METODE PENELITIAN}

Dalam penulisan ini, baru dikatakan ilmiah bila telah menggunakan metode ilmiah, yakni presedur dan langkahlangkah sistematis untuk mendapatkan pengetahuan-pengetahuan ilmiah (ilmu tertentu). Sedangkan metode penelitian adalah tata cara yang menjelaskan tentang bagaimana suatu penelitian dilaksanakan (methods = tata cara). (Iqbal Hasan, 2002: 21). Metode yang digunakan dalam penelitian ini adalah metode deskriptif dan analisis komparatif (analytical comporative method). Dalam pembahasan dan penelitian dan pengumpulan data ini, penulis memakai teknik pengumpulan bahan melalui metode kepustakaan (library research) yaitu dengan mengumpulkan data dan bahan-bahan dari buku yang relevan dengan pembahasan ini, dengan cara membaca, mempelajari, dan menganalisa untuk dapat dipahami.

\section{PEMBAHASAN}

\section{Memaknai Sosiologi Dan Antropologi Hukum}

\section{Sosiologi Hukum}

Sosiologi hukum (sociology of low) the sociological study of the social context, development, and operation of law: the syistem of rules and sanctions, the specialist institutions and specialist personal, and the several types of low (for example, constitutional, civil, criminal) that constitute the legal system in complex socienties (David Jarry \& Julia Jary, n.d: 477).

Maka dapat dipahami bahwa sosiologi hukum (sociology of law) adalah pengetahuan hukum terhadap pola perilaku masyarakat dalam konteks sosialnya. Dan juga sosiologi hukum adalah ilmu yang mempelajari hubungan timbal balik antara hukum dengan gejala-gejala sosial lainnya secara empiris analisis. Sociology af the law, menjadikan hukum sebagai alat pusat penelitian secara sosiologis yakni sama halnya bagaimana sosiologi meneliti suatu kelompok kecil lainnya. Tujuan penelitian adalah selain untuk menggambarkan betapa penting arti hukum bagi masyarakat luas juga untuk menggambarkan proses internalnya hukum.

Ruang lingkup sosiologi hukum secara umum, yaitu berkisar pada: 
a. Mempelajari dasar sosial dari hukum, berdasarkan anggapan bahwa hukum timbul dari proses sosial lainnya (the genetic sociology of law).

b. Mempelajari efek hukum terhadp gejala-gejala sosual lainnya dalam masyarakat (the operational sociology of law).

Adapun persepektif penelitian sosiologi hukum dapat dibedakan antara:

a. Sosiologi hukum secara teoritis bertujuan untuk menghasilkan generaliasi atau abstrak setelah pengumpulan data, pemeriksaan terhadap keteraturan sosial, dan pengembangan hipotesis (yang didalamnya selalu terdapat hubungan sebab akibat).

b. Sosiologi hukum empiris atau praktis, yang bertujuan untuk menguji berbagai hipotesis tersebut melalui pendekatan yang sistematis dan metodologis.

Sosiologi adalah suatu kajian ilmiah tentang kehidupan masyarakat manusia. Sosiolog (ahli sosiologi) berusaha mengadakan penelitian yang mendalam tentang hakikat dan sebabsebab dari berbagai keteraturan pola pikiran dan tindakan manusia secara berulang-ulang. berbeda dengan psikolog, yan memfokuskan sasaran penelitiannya kepada berbagai karekteristik pikiran dan tindakan perorangan, sosiolog hanya tertarik pada pikiran dan tindakan yang dimunculkan seseorang sebagai anggota suatu kelompok atau masyarakat (Dadang Kahmad, 2002: 9). Sosiologi hukum penting bagi yang bekerja sebagai perumus hukum yang akan diberlakukan, penting yang akan menjalankan hukum, dan penting bagi penguasa dan rakyatnya. Perumus hukum adalah perwakilan rakyat, maka setiap anggotanya terlibat dalam perumusan hukum, yakni pemerintah dan wakil rakyat. Apa yang hendak dirumuskan dan kemana hukum hendak dibawa tidak terlepas dari penghayatan terhadap aspirasi masyarakat dan nilai-nilai luhur (Bustanuddin Agus, 2012: 4).

Dengan demikian itu, bahwa terjadinya perbedaan di antara para pakar tentang pendefenisian hukum disebabkan oleh perbedaan sudut pandang.Betapa luas aspek hukum sehingga menimbulkan beragam defenisi yang luas cakupannya. Hukum terkadang dipandang dari sudut sosiologi, hukum biasanya ditinjau dari aspek kesejarahan, serta hukum adakalanya dilihat dari segi filsafat, dan dari segi agama.

\section{Antopologi Hukum}

Hubungan yang cukup lama antara sistem hukum dari masyarakat dan kebudayaan-kebudayaan lain (the other cultures) selain state law (hukum negara) menjadikan sistem- sistem hukum tersebut berjalan secara dinamis sesuai dengan laju kebudayaannya. Sebagian pihak menganggap the other laws bagian dari masa lalu, namun sebagian lagi menyatakan bahwa mereka tetap eksis hingga kini. Dan, sebagian lainnya menyatakan ada, namun semakin terkikis (Pasudi Suparlan, 1980: 20-23). 
Implikasi konkrit di lapangan dari unifikasi hukum ini patut diduga terjadinya tumpang tindih, ambivalensi dan ketidak pastian hukum salah satu fakta yang terjadi adalah: a) dari sisi masyarakat pemilik hukum lokal, mereka semakin tidak leluasa dalam mengimplementasikan hukumnya, b) dari sisi state, hukum-hukum lain ditanggapi sebagai ganjalan yang dapat menghambat proses pembangunan (semesta) (Roger M. Keesing, 1992: 294).

Gesekan antara dua kutub diatas memang acapkali disikapi dengan disharmonisasi hubungan keduanya, dan pasang surut hubungan keduanya memunculkan dinamika dalam perilaku, norma dalam masyarakat. Hukum memiliki banyak dimensi, oleh karenanya di kalangan ilmuwan (hukum) tidak ada kesepakatan yang tunggal tentang pengertiannya. Menurut J.M Otto, Pada umumnya hukum diartikan sebagai seperangkat rules of conduct yang mengatur dan memaksa masyarakat, juga mengatur tentang penyelesaian sengketa (Sulistyowati Irianto, 2012: 1-2).

Studi hukum di negara berkembang memerlukan kedua pendekatan baik pendekatan ilmu hukum maupun ilmu sosial. Pendekatan dan analisis ilmu hukum diperlukan untuk mengetahui isi dari legislasi dan kasus hukum. Namun pendekatan ini tidak menolong memberi pemahaman tentang bagaimana hukum bekerja dalam kenyataan sehari-hari, dan bagaimana hubungan hukum dengan konteks kemasyarakatan. Oleh karena itu dibutuhkan pendekatan interdisipliner yang bersifat holistik, yaitu konsep dan teori dari berbagai disiplin ilmu dikombinasikan dan digabungkan untuk mengkaji fenomena hukum, yang tidak diisolasi dari konteks sosial, politik, ekonomi, budaya, di mana hukum itu mengalir.

Menurut Ihromi (Sartono Sahlan, 2010: 150), relevansi menelaah hukum dari segi antropologi, antara lain adalah: (a). Berkenaan dengan masalah yang dihadapi oleh negara-negara berkembang (tentunya termasuk Indonesia) yang secara budaya bersifat pluralistis dalam cita-citanya mewujudkan unifikasi hukum atau modernisasi hukum; (b). berkenaan dengan kemungkinan munculnya masalah bila warga masyarakat dari lingkungan sukubangsa tertentu masih mempunyai norma-norma tradisional yang kuat dan menuntut ketaatan mengenai hal-hal tertentu, sedangkan dalam norma hukum yang sudah tertulis dan berlaku secara nasional, hal- hal yang harus ditaati itu justru dirumuskan sebagai hal yang terlarang.

Implikasi pendekatan semacam ini menjadikan bahwa hukum memberi input kepada pranata pengendalian sosial (apapun variant-nya) dan kemudian kepada rujukan berpikir masyarakat, dan sebaliknya. Hukum, di sisi lain, dapat pula menyebabkan perubahan perangkat berpikir, dan rujukan kemasyarakatan lainnya atau dikenal dalam sosiologi hukum sebagai "law as tool of social engineering".

Pendekatan antropologi hukum sengaja menggeser pusat perhatian dari aturan-aturan kepada individu atau manusia sebagai aktor yang dalam mengambil keputusan mengenai 
perilakunya dihadapkan kepada tuntutan-tuntutan dari tatanan hukum yang dihadapinya (Ihromi, 2003: 3).

$$
\text { Kajian antropologi hukum }
$$

memiliki karakteristik metode penelitian yang dapat diidentifikasi melalui dua hal berikut ini.Pertama, seorang antropolog hukum melakukan studi tekstual, pasal-pasal dalam peraturan perundang-undangan dan kebijakan yang dapat dianalisis secara kritikal dan dijelaskan makna dan implikasinya terhadap subjek hukum.Kedua, studi sosio-legal mengembangkan berbagai metode 'baru' hasil perkawinan antara metode hukum dengan ilmu sosial, seperti penelitian kualitatif sosio-legal, dan etnografi sosiolegal. Pada umumnya para antropolog hukum mengembangkan etnografi hukum untuk mengkaji forum penyelesaian sengketa berbasis komunitas yang biasa dijumpai dalam kehidupan keseharian. Para peneliti yang mempelajari pluralisme hukum mengembangkan metode etnografi hukum modern seiring dengan isu-isu global yang membuat pendekatan pluralisme hukum semakin tajam memandang fenomena keberagaman hukum. Metode yang dikembangkan secara interdisipliner itu dapat menjelaskan fenomena hukum yang sangat luas, dan keterkaitannya dengan relasi kekuasaan dan konteks sosial, budaya dan ekonomi di mana hukum berada (Sulistyowati Irianto, 2012: 7).

Dalam penelitian Antropologi hukum terdapat tiga cara yang pokok sebagai berikut: (a). ideologi, penelitian ini hendaklah bersifat etnologi hukum (setempat), yaitu berdasarkan pengarahan etnologi yang mempelajari lembaga - lembaga hukum dari suatu masyarakat tertentu. Titik tolaknya pada anggapan bahwa sebelum penelitian sudah ada pengertian hukum. Penelitian ini dapat dilakukan dalam bentuk penjajakan (eksploratif) dengan mempelajari kaidah - kaidah hukum yang ideal, baik yang tertulis atau tidak tertulis; (b).diskriptif, penelitian ini digunakan untuk mengetahui hal - hal yang praktis dengan melihat pola perilaku yang sesungguhnya terjadi, metode ini tidak mengutamakan perhatiannya pada apa yang tertulis sebagai norma hukum, atau yang dikatakan norma hukum oleh para pemuka masyarakat, melainkan tujuannya untuk mengetahui sejauh mana aturan aturan tersebut dapat diterima anggota masyarakat; (c). studi kasus (meneliti permasalahan), untuk mengetahui hukum kausalitas dari berbagai kasus yang ada. Perselisihan kepentinganyang berakhir pada suatu kasus - kasus merupakan salah satu bagian dari metode ini, sebagaimana yang dikatakan oleh Roscoe Pound yang dikutip oleh Hilman Hadikusuma: "Jadi hukum itu berperan di sekitar adanya pertentangan kepentingan, karena hukum itu merupakan usaha untuk mendamaikan, menyelaraskan, untuk mempertemukan...kepentingan yang berlebihan atau yang bertentangan" (Hilman Hadikusuma, 2013, 38). Namun, kesimpulan ini tidak dapat digeneralisasikan pada semua bagian hukum yang ada. Dalam penelitian 
terhadap kasus - kasus perselisihan memerlukan pendekatan yang eklektika, yang berpandangan luas dan pluralitas.

\section{Dinamika Hukum Islam Pada Masa Ijtihad Dengan Mempertimbangkan Sosiologi Dan Antropologi Hukum}

\section{Masa Shahabat}

Pengertian shahabat menurut terminologi ulama fiqh dan ushul fiqh adalah setiap orang yang pernah bertemu dengan Nabi Muhammad Saw. dalam status iman kepadanya, dan meninggal dunia dalam keadaan beriman pula.

اجتهد الصحابة : رضوان الله عليهخ في حياة الرسول الله صلى الله عليه و سلم

سواء في حال وجوده معهم في مجلسه -

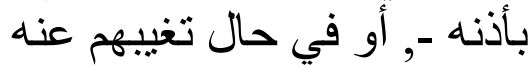

"Shahabat ber-ijtihad: Allah SWT meredhai mereka pada kehidupan Rasulullah SAW sama ada dalam keadaan adanya pada majelis Rasulullah - dengan izinnya- atau pada keadaan ketidakhadiran (ghaib) mereka pada majelis Rasulullah" (Usman bin Muhammad al-Akhdar Syausany, tt: 108).

Masa mulai dari periode khulafaur Rasyidin dan shahabatshahabat yang senior, hingga lahirnya Imam Madzhab yaitu dari tahun 11-132 H. Ini meliputi periode khulafaur Rasyidin $(11-40 \mathrm{H}=632-661 \mathrm{M})$. و هكذا كانت وفاة النبى صلى الله عليه وسلم أذن أول عامل من العوامل التى الاجتهاد يدخل في دور أعظم اهتماما به من قبل, و و العن الهن أكثر لجوءا اليه
"Sungguh seperti inilah wafat Nabi SAW telah diizinkan orang yang mengamalkan pertama kali dari amal-amal yang masuk ijtihad dalam perhatian yang besar dibandingkan sebelumnya dan telah banyak yang membolehkannya".

Pada masa ini daerah kekuasaan Islam semakin luas, meliputi beberapa daerah di luar semenanjung Arabia, seperti Mesir, Syria, Iran (Persia) dan Iraq. Dan bersamaan dengan itu pula, agama Islam berkembang dengan pesat mengikuti perkembangan daerah tersebut.

Di periode shahabat ini, kaum muslimin telah memiliki rujukan hukum syari'at yang sempurna berupa Al-qur'an dan Hadits Rasul. Kemudian dilengkapi dengan ijma' dan qiyas, diperkaya dengan adat istiadat dan peraturan-peraturan berbagai daerah yang bernaung dibawah naungan Islam. Dapat kita tegaskan bahwa di zaman khulafaur Rasyidin lengkaplah dalil-dalil tasyri Islami (dasar-dasar fiqh Islam) yang empat, yaitu: Al-Kitab, As Sunnah, Al-Qiyas atau ijtihad, atau ra'yu dan ijma' yang bersandar pada Al-Kitab, atau As-Sunnah, atau Qiyas.

وفي عهد الصحابة و اجهتهم وطر أت لهم طوارى, لو تواجه المسلمين ولم تطر أ لهم في عهد الرسول, فاجتهد فيها أهل الاجتهاد

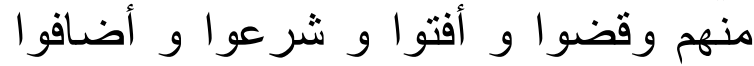

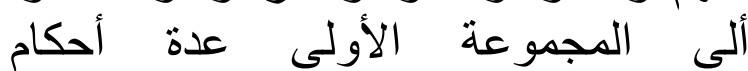

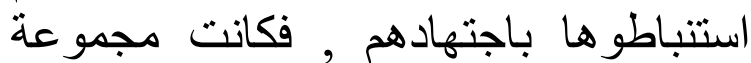

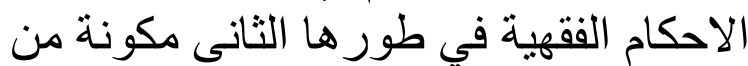
احكام الله و رسولله و فتاوى الصحابة و هو هونه أقضنيهم.

"Pada masa shahabat dan ijtihad mereka dan perkembangan sebagaimana perkembangan mereka, walaupun dari 
penjelasan orang-orang muslim dan belum terjadi pada masa Rasulullah SAW. Maka di antara mereka berijtihad, mengadili, memberi fatwa, menetapkan hukum, dan menyandarkan dengan semua kumpulan awal yang beragam penetapan hukum dengan ijtihad mereka. maka kumpulan hukum fiqhiyah dalam perkembangannya padac dekade ke 2 yang terbentuk dari hukum Allah, Rasul, fatwa shahabat, dan ketetapan mereka" (Abdul Wahab Khalaf, n.d.: 15).

Shahabat-shahabat besar dalam periode ini menafsirkan nash-nash hukum dari Al Qur'an maupun dari Al Hadits, yang kemudian menjadi pegangan untuk menafsirkan dan menjelaskan nash-nash itu. Selain itu para shahabat besar memberi pula fatwa-fatwa dalam berbagai masalah besar memberi pula fatwa-fatwa dalam berbagai masalah terhadap kejadiankejadian yang tidak ada nashnya yang jelas mengenai hal itu, yang kemudian menjadi dasar ijtihad.

\section{a. Metode dalam Mengenal Hukum}

Para Khulafaur Rasyidin dalam menghadap suatu masalah atau berbagai masalah mereka lebih dahulu mencari nashnya dari Alquran atau Sunnah, kalau mereka tidak menemukan dalam Alquran dan Sunnah mereka mengadakan pertemuan dengan fuqoha shahabat untuk meminta pendapat mereka. Apabila mereka telah sepakati suatu pendapat, maka mereka menetapkan pendapat itu sebagai suatu keputusan. Inilah yang disebut ijma'

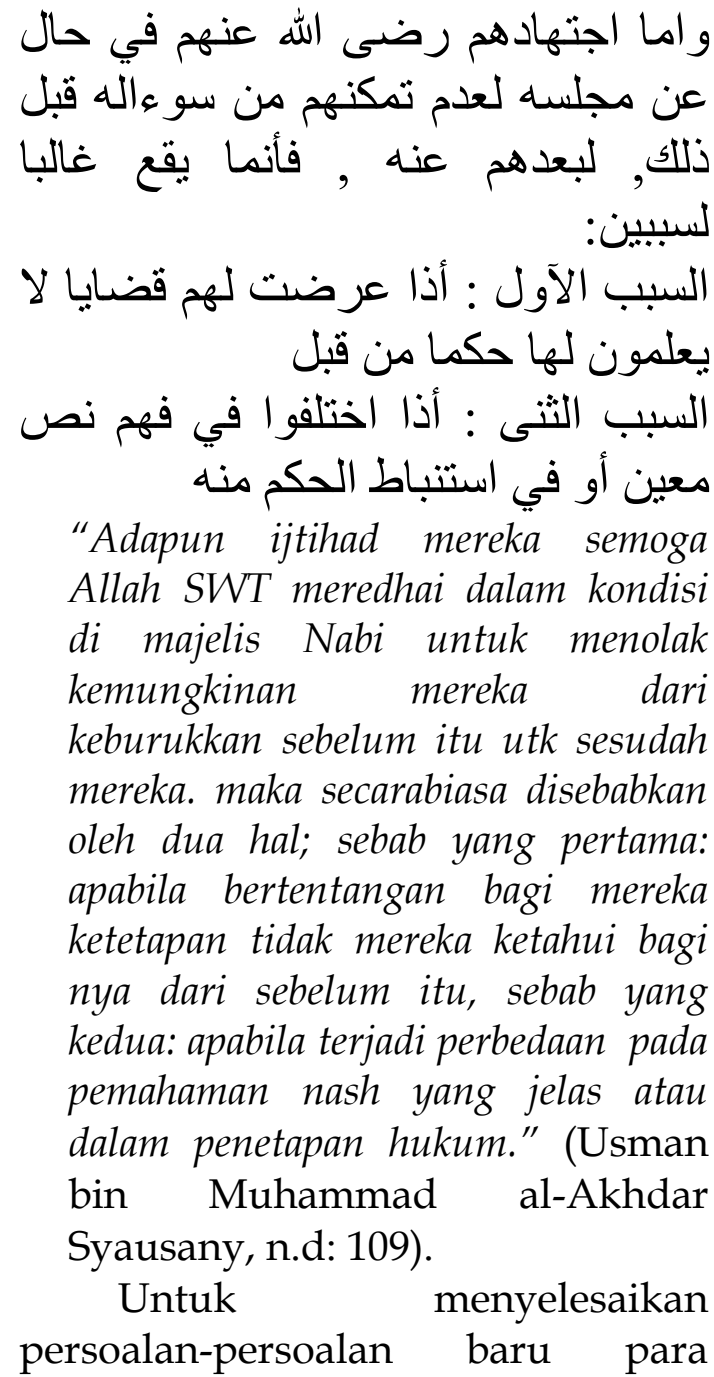
shahabat kembali kepada Alqur'an dan Sunnah Nabi. Para shahabat banyak yang hafal Alqur'an, kendati pernah timbul keresahan ketika banyak yang gugur ketika menghadapi peperangan. Karenanya kembali kepada Alqur'an itu mudah. Hadits memang diriwayatkan dan dihafal. Tetapi nasib hadits tidak sebagus Alqur'an karena perhatian mereka lebih terpusat kepada Alqur'an. Disamping dihafal, Alqur'an juga ditulis. Namun demikian, sumber hukum Islam dimasa ini adalah Alqur'an dan 
hadits. Berdasar kedua sumber hukum itulah para kahlifah dan shahabat berijtihad dengan menggunakan akal pikiran.

Pada umumnya dalam memutuskan hukum, shahabat tidak sendirian, tetapi bertanya terlebih dahulu kepada shahabat lain, takut kalau salah. Sikap ini menunjukkan bahwa penafsiran terhadap Alqur'an bukan hak perogratif shahabat. Selanjutanya keputusan diambil dari hasil consensus, yang lazim disebut ijma'. Melihat luasnya kekuasaan Islam, tetapi kesepakatan beberapa pemuka Islam yang dipandang mewakili keseluruhan.

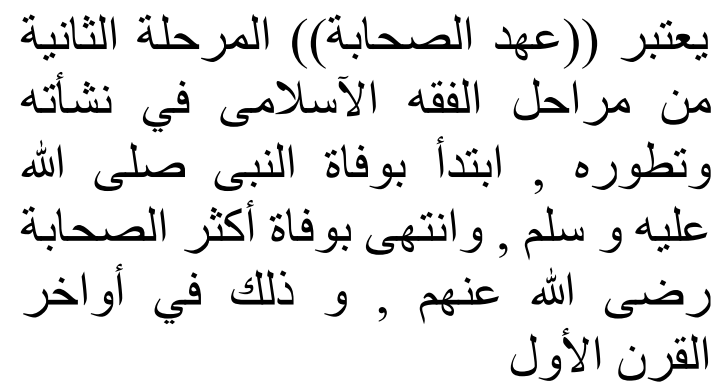

"Terkenal (masa shahabat) tahapan kedua dari tahapan figh Islamy dalam pertumbuhan dan perkembangannya, dimulai dengan wafat nabi SAW dan berakhir dengan wafat banyak dari shahabat, itu pada akhir abad pertama" (Usman bin Muhammad al-Akhdar Syausany, n.d: 114).

Pada awal masa shahabat ini, yaitu pada masa khalifah Abu Bakar dan masa kholifah Umar, para shahabat dengan cara bersamabersama menetapkan hukum terhadap sesuatu yang tidak ada nashnya. Hukum yang di keluarkan oleh para shahabat dengan cara bersama-sama ini di sebut sebagai ijma' shahabat.
Khalifah Umar pun berbuat demikian, yaitu apabila sulit baginya mendapatkan hukum dalam Alqur'an dan as-Sunnah, maka diperhatikan apakah telah ada keputusan-keputusan terhadap masal itu. Jika Abu Bakar mendapatkan suatu keputusan hukum, maka Umar memutuskan dengan hukum itu, dan kalau tidak maka beliau memanggil pemukapemuka kaum muslimin, apabila sepakat tentang hukum tersebut, maka belau memeberikan keputusan dengan hukum yang telah di sepakati tersebut.

Metode yang digunakan pada masa shahabat dapat ditempuh melalui beberapa cara diantaranya :

1) Dengan semata pemahaman lafaz yaitu memahami maksud yang terkandung dalam lahir lafaz. Umpamanya bagaimana hokum membakar harta anak yatim. Ketentuan yang jelas dalamm alquran hanya larangan memakan harta anak yatim. Ketentuan jelas dalam alquran hanya larangan memakan harta anak yatim secara aniaya, sedangkan hukum membakarnya tidak ada. Karena semua orang itu tahu bahwa membakar dan memakan harta itu sama dalam hal mengurangi atau menghilangkan harta anak yatim, maka keduanya juga sama hukumnya yaitu haram. Cara ini kemudian disebut penggunaan metode mafhum.

2) Dengan cara memahami alasan atau illat yang terdapat dalam suatu kasus (kejadian) yang baru, kemudian menghubungkannya 
kepada dalil nash yang memiliki alasan atau illat yang sama dengan kasus tersebut. Cara ini kemudian disebut metode qiyas.

\section{b. Keistimewaan Takhrij Pada Masa Shahabat}

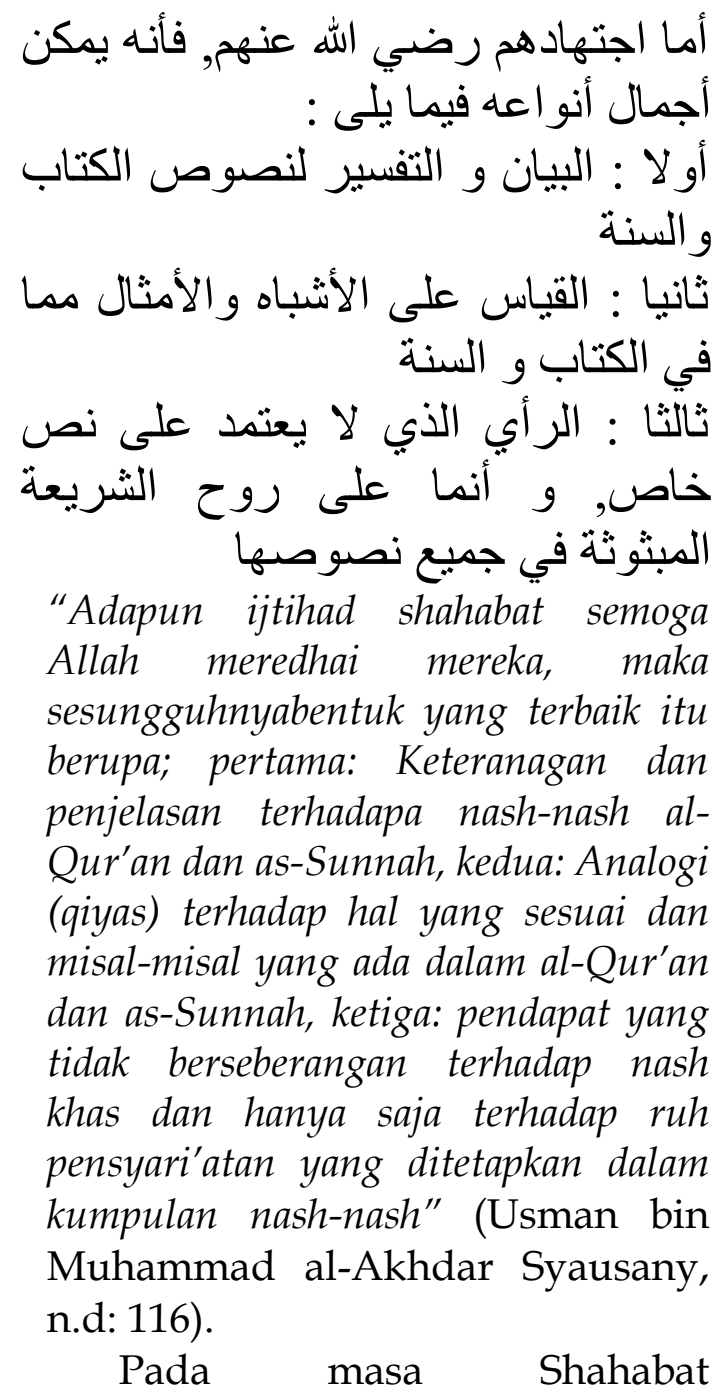
merupakan masa perkembangan fiqh yang diistilahkan sebagai masa muda remaja yang dimulai dari periode Khulafaur Rasyidin dan shahabat-shahabat senior hingga lahirnya imam mazhab dari tahun 11-132 H. Meliputi periode Khulafaur Rasyidin (11-40 H = 632-
$661 \mathrm{M})$ dan periode Umayyah (40$132 \mathrm{H}=661-750 \mathrm{M})$. Keistimewaan yang menonjol pada masa Khulafaur Rasyidin, yaitu:

1) Kodifikasi ayat-ayat al-Qur'an serta menyebarkannya yang dimaksudkan untuk mempersatukan umat Islam dalam satu wajah tentang bacaan al-Qur'an agar tidak ada perbedaan yang berakibat perpecahan.

2) Pertumbuhan tasyri' dengan $r a^{\prime} y u$ sebagai motivasi besar terhadap para fuqaha untuk menggunakan rasio sebagai sumber ketiga yaitu qiyas.

Setelah masa Khulafaur Rasyidin kemudian diganti dengan masa Dinasti Umayyah, berkembanglah Ahlul Hadist di samping Ahlu Ra'yi. Bahkan perbedaan pendapat antara 2 kelompok ini semakin tajam pada dinasti Abbasiyah (132-656 H) dan kian bertambah subur dan berkembang dengan baik serta menjadi gerakan ilmiah yang berpengaruh luas yang kemudian melahirkan mazhab-mazhab fiqhi dalam Islam.

Keistimewaan pada periode Khulafaur Rasyidin bahwa fiqh pada masa ini muncul sesuai dengan perjalannya waktu. Dalam artian, kapan ada suatu permasalahan yang tidak terdapat di dalam Nash, maka para mujtahidin berusaha menggali hukumnya dari Alqur'an dan sunnah. Dalam masa ini terjadi pengumpulan Alqur'an dan menjadikannya dalam satu mushaf. 
Hal ini terjadi karena untuk menghindari perpecahan diantara umat islam yang sudah mulai merambah ke seluruh tanah arab. Dalam masa ini juga belum ada periwayatan hadits, kecuali jika ada sebuah kebutuhan untuk mengetahui suatu hukum. Di masa ini juga telah menghadirkan sumber hukum baru yaitu ijma'. Dan ini banyak sekali timbul permasalahan yang merujuk pada ijma'.

Adapun peninggalanpeninggalan masa shahabat yang ada hubungannyadengan fiqh ialah:

1) Penjelasan-penjelasan yang bersifat yuridis terhadap nashnash hukum Alqur'an dan asSunah. Penjelasan-penjelasan yang demikian iti terjadi, ialah ketika shahabat membahas nashnash hukum untuk di terapkan kepada kejadian-kejadian lalu timbul pendapat-pendapat tentang pengertian dan maksud sebenarnya dari nash-nash. Dalam melahirkan pendapat-pendapat itu mereka bersandar pada bakat serta kemampuan mereka dalam bidang bahasa, pada bakat serta kemampuan mereka dalam penetapan hukum dan pada pengetahuan mereka, tentang hikmah diturunkannya syari'at serta sebab -sebab turunnya al;qur'andan di datangkannya alhadits. Dari kumpulan pendapatpendapat itu terbentuklah syarah yang bersifat yuridis terhadap nash-nash hukum, yang syarah itu dianggap sebagai landasan terpercaya dalam menafsirkan nash-nash tersebut dan untuk menjelaskan keumumannya dan nash serta cara-cara penerapannya.

2) Fatwa-fatwa hasil ijtihad yang di berikan oleh tokoh-tokoh shahabat, terhadap kejadiankejadian yang tidak ada nashnya. Cara mujtahid dikalangan shahabat itu apabila tidak mendapatkan nash dalan Alqur'an atau as-sunah tentang hukum sesuatu kejadian yang diajukan. Mereka berijtihad untuk menemukan hukum dengan berbagai jalan istinbath. Mereka sangat dekat dan bertemu langsung dengan Nabi Saw., sehingga memudahkan mereka untuk mengetahui asbabun nuzul ayat dan asbabul wurud hadis. Mereka juga mengetahui penafsiran Rasulullah tentang beberapa ayat disamping juga mengetahui 'illat hukum dan hikmahnya, sehingga memudahkan dalam melakukan qiyas nash-nash yang ada kemiripan lalu menetapkan hukumnya. Mereka memiliki pemahaman yang tinggi terhadap bahasa Arab yang merupakan bahasa Alquran. Mereka menghafal Alquran dan sunnah Rasulullah Saw., menjadi orang pertama yang mempelajari ilmu syariat dan hukumnya.

\section{c. Contoh ijtihad yang dilakukan pada masa shahabat}

Ijtihad adalah pengerahan kesungguhan dalam mengeluarkan hukum syara' dari apa yang dianggap syari' sebagai dalil yaitu 
kitabullah dan Sunnah Nabi SAW. ini dibagi dua macam yakni:

1) Mengambil hukum dari yang zhahir-zhahir nash apabila hukum itu diperoleh dari nashnash itu.

2) Mengambil hukum dari ma'qul nash karena nash itu mengandung 'illat yang menerangkannya, atau 'illat itu dapat diketahui dan tempat kejadian yang di dalamnya mengandung 'illat, sedang nash itu tidak memuat hukum itu. Inilah yang dinamakan dengan qiyas. (Hudhari Bik, 1980: 256)

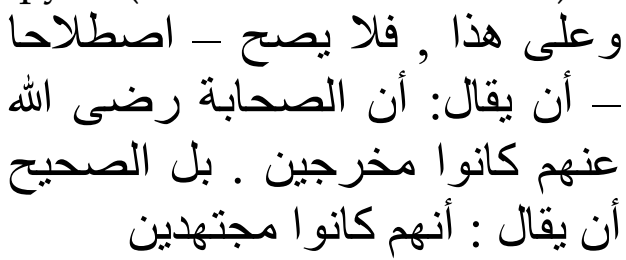

Dan terhadap ini, maka tidak benar - istilah - bahwa dia (asySyausyani) mengatakan: bahwa shahabat semoga Allah meredhai mereka tentang mereka orangorang yang keluar, tetapi yang benar adalah dia mengatakan : bahwa shahabat itu merupakan para mujtahid" (Usman bin Muhammad al-Akhdar Syausany, n.d: 127).

Di antara beberapa contoh ijtihad yang dilakukan oleh shahabat, antara lain:

1) Memerangi orang yang tidak mau membayar zakat

Diriwayatkan, Abu Bakar sebagai Khalifah pernah memerangi orang yang menolak membayar zakat. Umar bin alKhattab menegurnya dengan berkata, " Saya pernah disuruh Rasulullah memerangi orang sampai mereka mengucap la ilaha illa Allah. Kalau mereka sudah mengucapkannya, Allah menjaga harta dan darahnya, kecuali dengan "hak"nya. Semua urusan ditangan Tuhan". Abu bakar menyahut, " Demi Allah, sungguh saya akan memerangi siapa saja yang membedakan sholat dengan zakat. Sebab zakat termasuk "hak" nya atas harta.

2) Ahli waris

Pada zaman Umar Bin Khattab terdapat serombongan ahli waris yang terdiri dari suami(1/2) ibu $(1,6)$ dan tiga orang saudara seibu semuanya sesuai dengan ketentuan Alqur'an. Kebetulan dalam rombongan itu ada pula saudara laki-laki kandung yang berdasarkan hadits nabi adalah "ahli waris sisa harta". Karena harta sudah terbagi habis maka saudara kandung tidak dapat bagian apa-apa. Tidak dapatnya saudara kandung, sedangkan saudara seibu mendapat, tentu tidak enak dirasakannya. Dalam hal ini umar menetapkan bahwa saudara kandung bergabung dengan saudara seibu dalam mengambil hak $1 / 3$ harta yaitu hak saudara seibu. Hak istri atas peninggalan mendiang suaminya dijelaskan secara pasti dalam Alqur'an Surat An Nisa 12 yaitu 1/4 bila suami tidak meninggalkan anak dan $1 / 8$ bila suami 
meninggalkan anak. Istri ini tidak mendapat hak apa-apa bila sebelum suami mati istri sudah di cerai terlebih dahulu.

3) Hukuman diyat karena pengampunan salah seorang Wali

Ketika haji wada' Nabi menyuruh pilih keluarga korban dimaksud, qishas atau denda bagi pembunuh (pembunuh disengaja). Ini sesuai firman Allah dalam surat Al-Baqarah ayat 178 .

"Hai orang-orang yang beriman, diwajibkan atas kamu qishaash berkenaan dengan orang-orang yang dibunuh; orang merdeka dengan orang merdeka, hamba dengan hamba, dan wanita dengan wanita. Maka barangsiapa yang mendapat suatu pema'afan dari saudaranya, hendaklah (yang mema'afkan) mengikuti dengan cara yang baik, dan hendaklah (yang diberi ma'af) membayar (diat) kepada yang memberi ma'af dengan cara yang baik (pula). Yang demikian itu adalah suatu keringanan dari Tuhan kamu dan suatu rahmat. Barangsiapa yang melampaui batas sesudah itu, maka baginya siksa yang sangat pedih"

4) Pernikahan seorang wanita yang sedang dalam 'iddah

Tentang kasus semacam ini terdapat dalam sunnah maupun Alqur'an. Ali ra. dalam menjawab masalah ini berpegang pada prinsip umum, tidak ada "larangan abadi". Maka, cukuplah diberi hukuman fisik dan perceraian, serta "iddah ganda". Sementara Umar ra. dalam mengambil sikap keras itu karena menutup pintu kesalahan yang sama bagi orang lain.

Tentang iddah wanita yang kematian suami disebutkan oleh Allah secara pasti dalam Surat AlBaqarah ayat 234 yaitu 4 bulan 10 hari:

"Orang-orang yang meninggal dunia di antaramu dengan meninggalkan isteri-isteri (hendaklah Para isteri itu) menangguhkan dirinya (ber'iddah) empat bulan sepuluh hari. kemudian apabila telah habis 'iddahnya, Maka tiada dosa bagimu (para wali) membiarkan mereka berbuat terhadap diri mereka menurut yang patut. Allah mengetahui apa yang kamu perbuat.

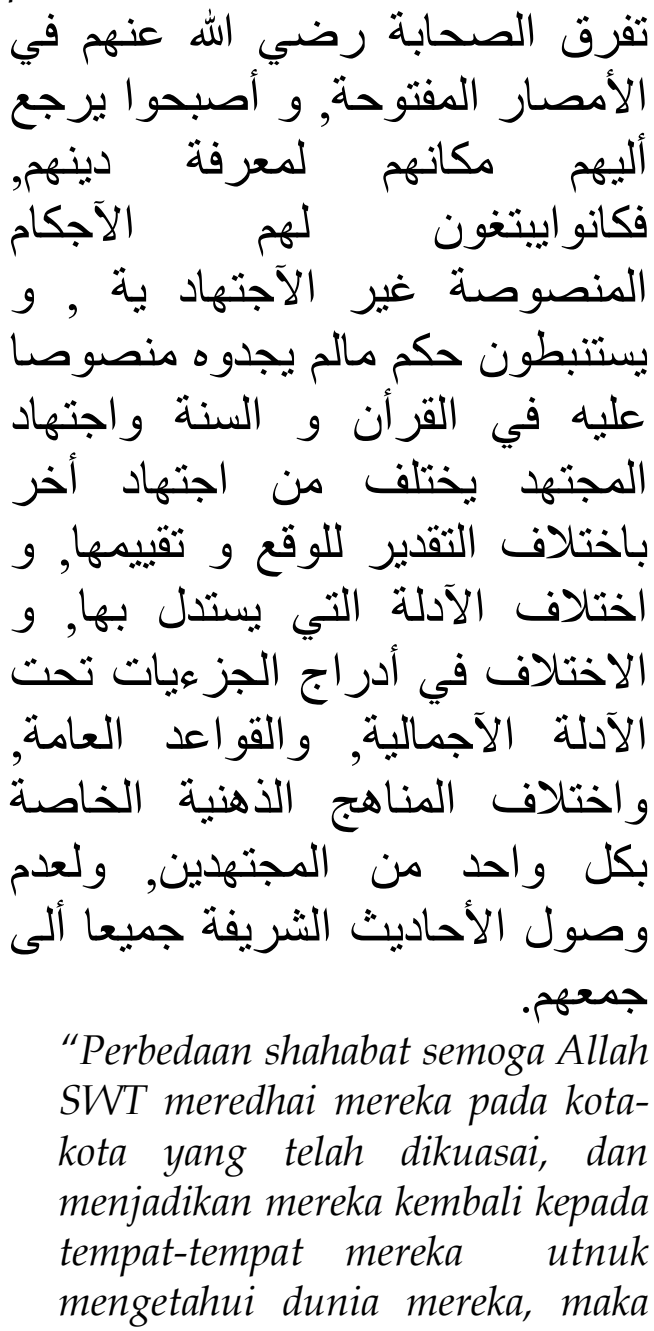


sungguh mereka mencari bagi mereka hukum-hukum nash tanpa ijtihad, mereka menetapkan hukum yang belum ditemukan nash terhadapnya berdasarkan Alqur'an, as-Sunnah dan ijtihad para mujtahid yang berbeda dari ijtihad yang lain dengan perbedaan ketetapan untuk kejadian dan tempatnya, dan berbeda dalil-dalil yang mereka jadikan dalil bagi nya, dan perbedaan pada tingkatan juz'i di atas dalil yang ijmali, dan qawaid umum, dan perbedaan manhaj mazhab yang khusus dengan setiap pribadi mujtahid dan menolak sampainya hadist-hadist yang mulia semua ke pada kumpulan-kumpulan mereka" (Sayyid Muhammad Musa, n.d: 56-57).

\section{Takhrij Pada Masa Tabi'in}

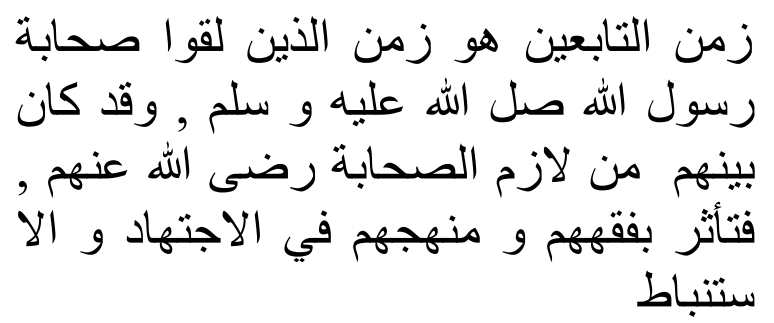

"zaman tabi'in adalah zaman orangorang yang bertemu dengan shahabat Rasulullah SAW, dan sungguh diantara mereka dari keleaziman shahabat semoga Allah meredhai mereka, berbekas dengan pemahaman, manhaj mereka dalam berijtihad dan beristibath" (Usman bin Muhammad al-Akhdar Syausany, n.d: 129).

Jadi dapat dipahami bahwa tabi' in adalah orang yang berjumpa dengan shahabat Nabi Shallallahu 'alayhi wasallam dalam keadaan ia beriman kepada Nabi Shallallahu 'alayhi wasallam meskipun ia tidak melihat Beliau Shallallahu 'alayhi wasallam dan ia mati di atas keislamannya. Di dalam kitab al-Hadits wa al-Muhadditsuun, menyetir pendapat al-Khatib, dikatakan bahwa Tabi'in adalah orang yang menyertai shahabat, tidak cukup hanya bertemu saja-seperti batasan arti shahabat, mereka cukup dengan hanya bertemu saja dengan Nabi Muhammad SAW, karena nilai kemuliaan, ketinggian budi Nabi. Berkumpul sebentar dengan Nabi bisa berpengaruh terhadap Nur Ilahi seseorang, sedangkian bertemu dengan orang lainnya tidak (termasuk dengan para shahabat) meskipun waktunya lebih lama. Sedangkan kebanyakan ahli hadits berpendapat bahwa, Tabi'in adalah orang yang bertemu shahabat meskipun tidak berguru kepadanya. Lain halnya dengan batasan al-Hakim, ia mendefinisikan tabi'in sebagai orang yang menjumpai shahabat dan pernah meriwayatkan daripadanya. Sedangkan dalam buku lain disebutkan, tabi'in adalah setiap muslim yang belum sempat melihat Nabi SAW namun ia sempat melihat dan bertemu dengan shahabat, baik ia meriwayatkan atau tidak darinya.

\section{a. Langkah - Langkah Tabi'in dalam Takhrij dan Tasyri'}

Bila artian sederhana tentang hukum Islam itu dihubungkan kepada pengertian fiqh sebagaimana dijelaskan sebelumnya, dapat dikatakan bahwa yang dimaksud dengan hukum Islam itu adalah yang bernama fiqh dalam literatur 
Islam yang berbahasa Arab. Dengan demikian, setiap kata fiqh dalam buku ini berarti hukum Islam (Amir Syarifuddin, 2009: 6).

Kajian tentang hukum Islam itu mengandung dua bidang pokok yang masing-masing luas cakupannya, yaitu: Pertama, kajian tentang perangkat peraturan terinci yang bersifat amaliah dan harus diikuti umat Islam dalam kehidupan beragama. Inilah yang secara sederhana disebut fiqh dalam artian khusus dengan segala lingkub bahasannya. Kedua, kajian tentang ketentuan serta cara dan usaha yang sistematis dalam menghasilkan perangkat peraturan yang terinci itu disebut ushul fiqh atau dalam arti lain sistem metodologi fiqh.

Rasulullah SAW wafat dan Abu Bakr r.a menjabat sebagai khalifah. Pada masa dijumpai sebagian besar bangsa Arab berpaling dari Islam. Cita-cita mantap dari Abu Bakr dan kekuatan Iman dalam hati orang Muhajirin dan orang Anshar adalah obat yang paling berguna untuk mengokohkan tiang-tiang Islam. Maka Abu Bakr menyiapkan menyiapkan beberapa bala tentara untuk dikirim ke Irak dan Syam, untuk menyiarkan dakwah Islam pada kerajaan Persi dan Rumawi, dan Abu Bakr meninggal sebelum itu terealisir dan belum diketahui siapa yang melanjutkannya (Hudhari Bik, 2008: 243).

Kemudian datanglah Umar, maka ditangannya sempurnalah penaklukan dan kaum Muslimin memerintah dari timur atas sebagian besar Persi hingga sampai sungai Jihon (Amudariya), dari utara atas Suriyah dan negeri Armenia. Dari barat atas Mesir. Pada zaman itu dibangun kota-kota Besar Islam seperti Fusthath, Kufah, dan Bashrah. Dan sebagian besar kaum Muslimin tinggal disana, di antara mereka banyak tedapat shahabat. Banyak orang-orang yang bukan bangsa Arab memasuki Islam.

Pada masa Ustman penaklukan-penaklukan itu meluas ke timur dan ke barat, hanya saja bangunan yang tinggi itu hampir tidak sempurna, karena tertimpa dengan pertarungan hebat, yaitu kehebohan melawan Amirul Mukminin Utsman bin Affan r.a, yang dimulai dengan permufakatan orang-orang yang membencinya dan berakhir dengan tindakan kumpulan tiga negara besar ke Madinah dimana mereka menghabisi hidupnya. Hal ini menjadi sebab perpecahan pendapat kaum Muslimin, yaitu satu golongan yang dendam atas Utsman dan merka adalah orang-orang yang membai'at Ali bin Abu Thalib r.a dan satu golongan yang dendam atas terbunuhnya Utsman dan mereka adalah orang-orang yang mengikuti Mu'awiyah bin Abi Sofyan r.a. Tempat tinggal golongan yang pertama adalah Kufah ibukota negeri Irak dan tempat tinggal golongan yang kedua adalah Damaskus ibukota negeri Syam. Dua golongan ini saling membenci satu sama lainnya dan yang satu saling mengutuk dan akhirnya masalah itu, menimbulkan perperangan besar 
antara golongan itu di padang Shiffin. Orang-orang yang berperang dari dua kelompok itu adalah orangorang pilihan di dunia Islam.

Di zaman tabi'in, permasalahan hukum yang muncul pun semakin kompleks. Para tabi'in melakukan ijtihad di berbagai daerah Islam (Nasrun Haroen, 1996: 8). Dalam masa tabi'in ini Islam semakin luas wilayahnya, kehidupan masyarakat juga semakin maju dan komplek. Penganut Islam pun bukan lagi hanya orang-orang Arab, tetapi sudah berbaur dengan bangsa lain yang berbeda-beda bahasanya. Perkembangan ini menyebabkan pengetahuan umat Islam akan sumber Islam yaitu Alqur'an dan alSunnah yang berbahasa Arab itu tidak lagi sesempurna orang sebelumnya. Di samping itu, permasalahan kehidupan yang memerlukan jawaban hukum semakin meningkat yang lebih menuntut pelaksanaan ijtihad.

Cara ulama tabi'in melakukan ijtihad adalah mengikuti cara yang sudah dirintis sebelumnya oleh shahabat. Mereka menggunakan Alqur'an dan al-Sunnah nabi sebagai rujukan utama. Selanjutnya mereka mengikuti ijma' shahabat. Jika tidak ditemukan dalam ijma' mereka berpedoman kepada hasil ijtihad pribadi dari shahabat yang mereka kuat dalilnya. Disamping itu, mereka menggunakan $r a^{\prime} y u$ sebagaimana yang dilakukan oleh shahabat. Dalam penggunaan $r a^{\prime} y u$ sedapat mungkin mereka tempuh melalui qiyas, bila mereka menemukan padanan masalahnya dengan apa yang terdapat dalam nash. Bila tidak mungkin, mereka menempatkan maslahatan umum sebagai bahan rujukan dalam berijtihad.

Dalam masa ini terlihat cara mereka melakukan ijtihad mengarah kepada dua bentuk, yaitu:

1) Kalangan shahabat yang lebih banyak menggunakan hadits atau al-Sunnah dibandingkan ra'yu. Cara ijtihad seperti ini berkembang di kalangan ulama Madinah dengan tokohnya Sa'id ibn al-Musayyab. Kalangan shahabat ini kemudian berkembnag dengan sebutan "Madrasah Madinah"

2) Kalangan shahabat yang lebih banyak menggunakan $r a^{\prime} y u$ dibandingkan dengan pengunaan al-Sunnah. Cara ijtihad seperti ini berkembang di kalangan ulama Kufah dengan tokohnya Ibrahim al-Nakh'i. Kalangan shahabat ini kemudian berkembang dengan sebutan "Madrash Kufah" (Amir Syarifuddin, 2009: 260).

Kenapa ulama Madinah lebih banyak menggunakan Hadits ketimbang $r a^{\prime} y u$ dan kenapa pula ulama Kufah atau Irak lebih menggunakan ra'yu ketimbang Hadits? Hal ini dapat dipahami dengan melihat kepada kondisi dan perkembangan masyarakat di dua lokasi yang berbeda ini. Kufah atau Irak adalah suatu wilayah yang lebih maju kehidupan masyarakatnya, sehingga masalah hukum yang dihadapinya sangat kompleks. Letaknya yang berjauhan dengan 
pusat kedudukan Nabi yang menyebabkan ulamanya lebih cenderung (terdorong) untuk menggunakan ra'yu. Sedangkan Madinah adalah suatu wilayah yang kehidupan masyarakatnya masih sederhana, sehingga masalah hukum yang dihadapinya tidak begitu kompleks. Di sisi lain mereka hidup di kalangan kaum yang berdekatan dengan Nabi sehingga banyak mempunyai koleksi Hadits. Karena diberikan jawabannya dengan Hadits Nabi yang banyak mereka ketahui. Hal ini menyebabkan mereka tidak begitu terdorong untuk menggunakan ra'yu.

Hasil yang dicapai oleh ijtihad ulama tabi'in ini, meskipun mereka mengikuti petunjuk dari cara ijtihad ulama shahabat, namun dalam beberapa hal mereka berbeda pendapat dengan ulama Shahabat, bahkan berbeda dengan apa yang berlaku pada waktu nabi. Ali bin Abi Thalib dan sebagian ulama shahabat menerima kesaksian salah seorang suami isteri terhadap yang lain dalam pengadilan. Begitu pula, mereka menerima kesaksian anakanak terhadap orang tua dan kesaksian orang tua terhadap anakanak. Tetapi Qadhi Syureih dan sebagian ulama tabi'in menerima kesaksian seperti itu, karena adanya unsur tuhmah dan kecintaan yang akan mempengaruhi mereka dalam kesaksiannya.

Dalam masa Nabi dan masa shahabat, perempuan biasa keluar rumah untuk pergi ke mesjid asal tidak memakai wewangian. Ulama tabi'in menetapkan tidak bolehnya perempuan keluar rumah untuk pergi ke mesjid karena pada masa itu banyak orang yang usil dan fasik yang akan menganggu perempuan yang keluar rumah (Amir Syarifuddin, 2009: 259).

Sa'id ibn al-Musayyab sebagai mujtahid tabi'in banyak menghasilkan ijtihad yang kelihatannya berbeda dengan apa yang diketahui sebelumnya. Seperti pendapatnya yang mengatakan bahwa seorang isteri yang ditalak tiga yang akan kemabli kepada suaminya yang pertama adalah cukup jika telah melakukan akad nikah dengan suami kedua dan tidak perlu bercampur terlebih dahulu. Beliau berdalil dengan umumnya firman Allah dalam surat al-Baqarah (2): 230;

"Kemudian jika si suami mentalaknya (sesudah talak yang kedua), maka perempuan itu tidak lagi halal baginya hingga dia kawin dengan suami yang lain. Kemudian jika suami yang lain itu menceraikannya, maka tidak ada dosa bagi keduanya (bekas suami pertama dan isteri) untuk kawin kembali jika keduanya berpendapat akan dapat menjalankan hukum-hukum Allah. Itulah hukum-hukum Allah, diterangkan-Nya kepada kaum yang (mau) mengetahui".

Pendapat berbeda dengan pendapat ulama shahabat yang berpedoman kepada Hadits Nabi yang mengatakan bahwa isteri yang ditalak tiga itu baru boleh nikah lagi dengan suami pertamanya bila dia telah bercampur dengan suami kedua dan tidak cukup dengan akad 
nikah. Sa'id bin al-Musayyab juga menfatwakan bolehnya seseorang yang sedang junub untuk membaca Alqur'an asal tidak memegang mushaf Alqur'an itu. Pendapat ini berbeda dengan pendapat ulama sebelumnya. Masa tabi'in ini dalam hal pelaksanaan ijtihad dikenal sebagai masa perantara antara masa sahahabat dengan masa imam mujtahid, karena motode ijtihad yang dilakukan ulama ulama shahabat diperdalam dan dipolakan dalam masa tabi'in ini. Hasil yang telah dicapai masa tabi'in inilah yang dikembangkan secara sistematis dan terstruktur oleh imam mujtahid.

\section{b. Ijtihad dan Khazanah Fikihiyah di Zaman Tabi'in}

Ijtihad adalah pengerahan kesungguhan dalam mengeluarkan hukum syara' dari apa yang dianggap syari' sebagai dalil yaitu kitabullah dan Sunnah Nabi SAW. ini dibagi dua macam yakni:

1) Mengambil hukum dari yang zhahirzhahir nash apabila hukum itu diperoleh dari nash-nash itu.

2) Mengambil hukum dari ma'qul nash karena nash itu mengandung 'illat yang menerangkannya, atau 'illat itu dapat diketahui dan tempat kejadian yang di dalamnya mengandung 'illat, sedang nash itu tidak memuat hukum itu. Inilah yang dinamakan dengan qiyas. (Hudhari Bik, 2008: 256).

Pengeluaran hukum (istimbath) pada masa itu terbatas pada fatwafatwa yang difatwakan oleh orang yang ditanya tentang suatu peristiwa.
Mereka tidak meluaskan dalam menetapakan masalah-masalah dan menjawabnya, bahkan mereka tidak menampakkan pendapat tentang sesuatu sebelum sesuatu itu terjadi. Jika sesuatu itu terjadi maka mereka berijtihad untuk mengistimbathkan hukumnya. Oleh karena itu fatwafatwa yang dinukil dari shahabatshahabat besar adalah sedikit.

Dinamika sosial dan hukum Islam saling memiliki keterkaitan dalam melakukan perubahan. Satu sisi perubahan sosial karena hukum Islam. Di sisi lain, perubahan hukum Islam karena perubahan sosial. Keberadaan hukum Islam yang dibawa oleh Rasulullah Saw. dengan jelas merubah sosial masyarakat pada waktu itu dari masyarakat jahiliyyah yang berpegang kepada adat kebiasaan mereka menjadi masyarakat Islam yang berpegang kepada hukum Islam. Tetapi hukum Islam juga melakukan perubahan karena terjadinya perubahan sosial. Sesuai dengan kaidah fikih yang dibuat oleh fuqaha: "berubahnya fatwa dengan sebab berubahnya masa, tempat, keadaan (niat) dan adat kebiasaan." Dengan melakukan perubahan hukum, maka hukum Islam itu dinamis, dan mampu beradaptasi, sehingga hukum Islam itu op tu date sesuai dengan perkembangan zaman dan perubahan social (Fathurrahman az-Zhari, 2016).

\section{PENUTUP}

Sosiologi hukum; mempelajari, menjelaskan secara analitisempiris tentang persoalan hukum dihadapkan dengan fenomena-fenomena lain dimasyarakat.Hubungan timbal balik antara hukum dengan gejala-gejala sosial lainnya merupakan bagian yang 
tidak terpisahkan dalam mempelajari sosiologi hukum.

Pengembangan kajian hukum selalu bersifat dinamis dan adaptif terhadap kebutuhan zamannya. Hukum tidak hadir "terberikan" dalam kehidupan masyarakat untuk mengatur dan mengawasi dan memberikan sanksi, melainkan hukum merupakan interaksi manusia dengan dirinya pribadi, sesama manusia, alam dan Sang Maha Pencipta. Hal yang penting dapat diperhatikan adalah hukum tidak hanya berisi konsepsi normatif: hal-hal yang dilarang dan dibolehkan: tetapi juga berisi konsepsi kognitif. Tidak dapat dipungkiri, bahwasanya kajian hukum yang hanya berlandaskan metode normatif - yuridis atau normatif - positivistik hanya akan mengarah kepada hilangnya nilai substantif dalam hukum atau norma tersebut. Kajian Antropologi Hukum telah memberikan perspektif baru dan solusi alternatif dalam memahami hukum dan berbagai aspek yang muncul dari hukum itu sendiri.Kajian dengan pendekatan ini sangat membatu terhadap subjek dan objek dari hukum, dan menghindari praktek "cucuk cabut" dalam penyusunan dan penegakan hukum dalam masyarakat.

Periode shahabat dan tabi'in merupakan periode tafsir dan takmil (penjelasan dan penyempurnaan) Ijtihad adalah pengerahan kesungguhan dalam mengeluarkan hukum syara' dari apa yang dianggap syari' sebagai dalil yaitu kitabullah dan Sunnah Nabi SAW. ini dibagi dua macam yakni: a. Mengambil hukum dari yang zhahirzhahir nash apabila hukum itu diperoleh dari nash-nash itu.

b. Mengambil hukum dari ma'qul nash karena nash itu mengandung 'illat yang menerangkannya, atau 'illat itu dapat diketahui dan tempat kejadian yang di dalamnya mengandung 'illat, sedang nash itu tidak memuat hukum itu. Inilah yang dinamakan dengan qiyas

Para shahabat dan tabi'in sangat cerdas dalam menetapkan suatu ketetapan hukum. Hal ini dilihat dari pengembangan hukum dengan penetapan melalui ijtihad yang mengacu kepada nilai dari kajian sosiologi dan antropologi hukum.

\section{DAFTAR KEPUSTAKAAN}

Agus, Bustanuddin. 2012. Sosiologi Hukum. Padang.

az-Zhari, Fathurrahman. 2016. Dinamika Perubahan Hukum Dalam Islam. AtTahrir - Jurnal Pemikiran Islam.

Bik, Hudhari. 2008. Tarikh al-Tasyri' AlIslami (Sejarah Pembinaan Hukum Islam), alih bahasa Muhammad Zuhri. Semarang: Darul Ikhya Indonesia.

Hadikusuma, Hilman. 2013. Antropologi Hukum Indonesia. Bandung: PT. Alumni Bandung.

Haroen, Nasrun. 1996. Ushul Figh I. Jakarta: PT Logos Wacana Ilmu.

Hasan, Iqbal. 2002. Metodologi Penelitian dan Aplikasinya. Bogor: Ghalia Indonesia.

Ihromi. 2003. Antropologi Hukum Islam. Jakarta: Yayasan Obor Indonesia. 
Irianto, Sulistyowati dkk. 2012. Kajian Sosio Legal. Denpasar: Pustaka Larasan.

Jarry, David dan Julia Jary. n.d. The Harper Collins Dictionary Sociology. Harper Perennial A Division of Harper Collins Publisher.

Kahmad, Dadang. 2002. Sosiologi Agama. Bandung: PT Remaja Rosdakarya.

Keesing, Roger M. 1992. Antropologi Budaya (Jilid 1). Jakarta: Erlangga.

Khalaf, Abdul Wahab. n.d. Ushul Figh. Beirut: Dar- Alfikri.

Musa, Sayyid Muhammad. n.d. al-Ijtihad wa mada hajatuna ilahi fi haza al-asry. Darul Kutubal-Haditsah.
Sahlan, Sartono. 2010. The Other Laws di Era Otonomi Daerah (Studi Antropologi Hukum). Pandecta Fakultas Hukum UNNES Semarang.

Suparlan, Pasudi. 1980. Kebudayaan, Masyarakat dan Agama: Agama Sebagai Sasaran Penelitian Antropologi. Majalah Ilmu-Ilmu Sastra Indonesia (Indonesian Journal of Cultural Studies), 10(1).

Syarifuddin, Amir. 2009. Ushul Figh (Jilid 1). Jakarta: Kencana.

Syausany, Usman bin Muhammad alAkhdar. n.d. Takhrij al-Furu' 'Ala AlUshul Dirasah Tarikhiyah wa Minhajiyah wa Tabqiyah. Mamlikiyah. 